\title{
Effects of Accelerated Ripening Agents on the Fruit Quality of Pawpaw (Carica papaya)
}

\author{
Catherine Achese Orisa ${ }^{1^{*}}$, Comfort Imeh Usoroh ${ }^{2}$ \\ ${ }^{I}$ Department of Food Science and Technology, Rivers State University, Nkpolu Oroworukwo, Port Harcourt, \\ Rivers State, Nigeria \\ ${ }^{2}$ Department of Agriculture and Home Economics Education, Faculty of Education, University of Uyo, PMB \\ 1017, Uyo, Nigeria
}

*Corresponding Author: Catherine Achese Orisa, Department of Food Science and Technology, Rivers State University, Nkpolu Oroworukwo, Port Harcourt, Rivers State, Nigeria.

\begin{abstract}
The use of ripening agents has been on the increase today as they provide fruits the desired colour and taste within a short time. However, these ripening agents may pose health threats to humans. In this study, the effect of accelerated ripening agents on the fruit quality of pawpaw was investigated. Fresh unripe pawpaw fruits were placed in different containers and were fully ripened with kerosene fume and calcium carbide after 48 hrs. Pawpaw sample ripened naturally was used as control sample. Unripe, naturally and accelerated ripened pawpaw fruits were analyzed for physicochemical properties and sulphide and sulphate distributions using standard methods. The result revealed a decrease in total titratable acidity (TTA), pH and carbohydrate contents on ripening while sugar content increased significantly $(p<0.05)$. Calcium carbide ripened sample had significantly $(p<0.05)$ higher TTA than kerosene fumed and naturally ripened samples. $\mathrm{pH}$ and total available carbohydrate of pawpaw ripened naturally and with accelerated ripening agents were significantly $(p<0.05)$ similar. Accelerated ripening with calcium carbide and kerosene fume also resulted to a significant $(p<0.05)$ increase in moisture content while vitamin $C$ content decreased, but significantly ( $p<0.05)$ similar. Results of sulphate and sulphide distribution of the pawpaw fruits revealed that the carbide sample contained significantly $(p<0.05)$ high amount of sulphate and sulphide than kerosene fume ripened and unripe pawpaw samples. The use of calcium carbide for ripening of pawpaw is therefore not advisable. The findings of this study will be useful for consumers and food safety authorities in addressing the changes in health risks and nutritional changes associated with accelerated ripening of pawpaw fruit.
\end{abstract}

Keywords: Pawpaw, accelerated, ripening agents, calcium carbide, kerosene fume

\section{INTRODUCTION}

Ripening of fruit is a physiological process which changes the appearance, texture, flavor and aroma of the fruit [1]. It is a natural process which makes the fruit less green, soft and sweeter. It is also an irreversible phenomenon which involves some organoleptic, physiological and biochemical changes. Some of the physiological and biochemical changes during ripening include increased carbohydrate content, sugar increase, aromatic volatiles, flavor compounds, phenolic compounds and organic acids [2]. Fruit are classified based on their ripening and respiration rate either as climacteric or non-climacteric. Climacteric fruits are characterized by transient increase in both ethylene synthesis and respiration at an early stage of ripening. They include avocado, banana, cherimoya, mango, kiwifruits, apple, apricot, cucurbit, jackfruit, papaya, peach, pear, plum and tomato [3]. Non-climacteric fruit on the other hand does not show any increase in respiration and ethylene synthesis during ripening. They include citrus fruits, cherry, cucumber, grape, lemon, orange, pepper, pineapple, strawberry, etc.

Pawpaw (Carica papaya) is an herbaceous plant belonging to the family Caricaceae [4]. It is widely grown and cultivated in the tropical and subtropical regions of the world. Pawpaw is a climacteric fruit and the onset of ripening coincides with an increase in respiration and ethylene production. This is essential in order to induce molecular mechanisms responsible for 
physiological changes during ripening [5]. The production of ethylene during the ripening process is responsible for regulating molecular pathways which influences the development of sensorial and nutritional attributes of pawpaw fruits [6]. When fully ripened, the skin colour changes from immature green to fully reddish orange. The changes in outer colour of the skin of pawpaw fruit is a sign of ripening which is due to increase in the concentration of carotene and chlorophyll decrease [7]. Pawpaw is largely cultivated in Nigeria. At the unripe stage, it is consumed as cooked vegetable and used as an ingredient in salad preparation. At the fully ripen stage, it is consumed raw and also processed into different products such as jams, jelly and marmalades. They vary in sizes, shape and colour. The pulp has been reported to contain $42.28 \%$ starch, $15.5 \%$ sugar with deficiencies in protein and fat [8].

Accelerated or artificial ripening is a complex issue since fruit farmers apply unregulated artificial ripening agents in order to satisfy the increasing demand of these fruits. It is the process by which ripening is controlled either by gases or incomplete combustion. Accelerated fruit ripening is usually carried out by fruit sellers in order meet the high demand and make high profit of seasonal fruits. In some developed countries such as India, Bangladesh and other South Asian countries, a legal framework for fruit ripening is been provided in order to control artificial fruit ripening. However, in Nigeria and other African countries, there are no specific laws to regulate artificial fruit ripening [9].

Recently, the use of artificial fruit ripening agents such as calcium carbide, kerosene fumes, ethephon and ethylene has been on the increase as these ripening agents provide fruits the desired colour and taste within a short time [9]. However, these ripening agents may pose health threats to humans and the surroundings as well [10]. Direct consumption of calcium carbide has been reported to cause muscal tissue irritations in the abdominal region [9]. Siddiqui and Dhua [11] also reported cases of stomach disorder after the consumption of mangoes ripened with calcium carbide. Although several studies have been carried out on the effect of calcium carbide on the chemical properties of pawpaw, there is no information on the sulphate and sulphide distribution of pawpaw as affected by accelerated and natural ripening. To the authors' best of knowledge, there is no work found on the use of kerosene fumes for ripening pawpaw fruits. Iroka et al. [12] investigated the effects of induced ripening on the proximate, biochemical and mineral composition of pawpaw fruit. Ripening agents used were calcium carbide, dried plantain leaves, polyethene bags and smoking. This study therefore investigated the effects of accelerated ripening agents such as calcium carbide and kerosene fumes on the fruit quality of pawpaw fruit. Specific objectives of the study were to evaluate the physicochemical properties, sulphate and sulphite concentrations of pawpaw fruit ripened with these processes.

\section{Materials And Methods}

\subsection{Identification and Collection of Samples}

Pawpaw (Carica papaya) fruits were harvested from the Rivers State University school farm in the month of April 2019. Identification of the materials was done by a plant scientist in the department of Crop and Plant Science, Rivers State University to ascertain that the right materials were used for the research. All chemicals used were of analytical grade.

\subsection{Pawpaw Ripening Processes}

\subsubsection{Ripening with Calcium Carbide}

Fresh unripe pawpaw fruits were placed in a container (25 L rectangular). Then $10 \mathrm{~g}$ of calcium carbide powder was placed opposite the fruits in the container. The container was opened after $48 \mathrm{hrs}$ and all the samples were fully ripened as shown in Figure 1.

\subsubsection{Ripening with Kerosene Fumes}

Fresh unripe pawpaw fruits (Figure 2) were placed in an airtight container $(25 \mathrm{~L}$ round container). A flat-wick lighted kerosene lantern was placed at the center of the container and was allowed to burn until the oxygen inside was exhausted (the light went off in 10minutes). The samples were kept in the container for $24 \mathrm{hrs}$ and then exposed to open air for another $24 \mathrm{hrs}$. All the samples were fully ripened after the 24 hours exposure to air as shown in Figure 3.

\subsubsection{Naturally Ripened Pawpaw}

Fresh unripe pawpaw fruits (figure 4) obtained from the parent stock (tree) was allowed to naturally ripen at room temperature condition. Ripening took place after three weeks.

\subsection{Physicochemical Analysis}

Moisture content, $\mathrm{pH}$ and Vitamin $\mathrm{C}$ content of the ripened pawpaw fruits was carried out using the AOAC [13] method. Total available 
carbohydrate was determined using the manual Clegg Anthrone method of Osborne and Vogt [14]. The hand held sugar refractometer was also used in determining the total soluble solids ( ${ }^{\circ}$ Brix) of the fruits. Total titratable acidity was determined by weighing $6 \mathrm{~g}$ of the sample into a beaker and titrating each sample with $0.1 \mathrm{~N}$ $\mathrm{NaOH}$ to an end point and then calculated [14].

\subsection{Sample Preparation for Sulphide and Sulphate Analysis}

The fruit samples were washed with distilled water and raised with deionized water. The outer layer was sliced in bits and grind to form a wide area concentration placed in conical flask and well labelled. The inner layer part of the seed (endosperm) was cut in cubes and grind. A known weight $(2.0 \mathrm{~g})$ was measured into a conical flask and $20.0 \mathrm{ml}$ of deionized water set in mechanical shaker for 30 minutes. The filtrate was set taken to Hach Spectrophotometer for analysis as described below:

\subsubsection{Sulphide Analysis (Methylene blue method ASTM D4658)}

Sulphide content was determined using the methylene blue method as described by Moest [15].

\section{Reagents}

i. Sulphide reagent $1 \& 2$

ii. Sodium sulphide saturated solution: Hundred grams $(100 \mathrm{~g})$ of sodium sulphide hydrate was dissolved in $100 \mathrm{ml}$ of distilled water.

iii. Sulpide anti-oxidant buffer (SAOB): Eighty grams $(80 \mathrm{~g})$ of sodium hydroxide, $35 \mathrm{~g}$ of ascorbic acid and $67 \mathrm{~g}$ of EDTA was dissolved in $600 \mathrm{ml}$ of distilled water and made up volume with distilled water.

iv. Sodium sulphide stock solution: One mililitres $(1.0 \mathrm{ml})$ of the saturated solution described above was pipette into $50 \mathrm{ml}$ of SAOB and diluted to 1 litre distilled water.

\section{Procedure}

The stored program number for sulphide was entered. The display showed in $\mathrm{mg} / \mathrm{l} \mathrm{S}_{2}$ and the zero icon. The sample was filtered since it was turbid. A clean cuvette was filled with $25 \mathrm{ml}$ of the sample to be analyzed. Another sample cuvette was filled with $25 \mathrm{ml}$ of distilled water which served as the blank. One mililitres $(1 \mathrm{ml})$ of reagent 1 was added to both the blank and sample and swirl. One mililitres $(1 \mathrm{ml})$ of reagent 2 was added to both the blank and sample and swirl. The timer was pressed and a five-minute reaction programe began. The cuvettes were then allowed to stand undisturbed. After the timer beeped, the blank cuvette was inserted into the sample holder and covered tightly. The ZERO icon was pressed. The sample was inserted and the READ icon pressed. The result displayed in $\mathrm{mg} / \mathrm{l} \mathrm{S}_{2}$.

\section{Calibration procedure}

Four different concentrations were prepared.

Standard 1: Five mililitres $(5.0 \mathrm{ml})$ of sodium sulphide stock solution and $50 \mathrm{ml}$ of sulphide antioxidant buffer were measured and diluted to $100 \mathrm{ml}$ with distilled water ( $0.1 \mathrm{ppm})$.

Standard 2: One mililitres $(1.0 \mathrm{ml})$ of sodium sulphide stock solution and $50 \mathrm{ml}$ of sulphide antioxidant buffer were measured and diluted to $100 \mathrm{ml}$ with distilled water $(0.02 \mathrm{ppm})$.

Standard 3: Two mililitres $(2.0 \mathrm{mls})$ of calibration standard 1 was measured and $50 \mathrm{ml}$ of sulphide antioxidant buffer added, diluted to $100 \mathrm{ml}$ with distilled water $(0.002 \mathrm{ppm})$.

Standard 4: One mililitres $(1.0 \mathrm{mls})$ of $1.0 \mathrm{mls}$ of calibration standard 1 was measured and $50 \mathrm{ml}$ of sulphide antioxidant buffer added, diluted to $100 \mathrm{ml}$ with distilled water $(0.001 \mathrm{ppm})$.

A calibration curve was prepared using concentration and absorbance reading.

\subsubsection{Sulphate Analysis (Turbidometric test method ASTM D516-07)}

Sulphate content of the fruits was determined using the methylene blue method as described by Tabtabai [16]. A user-enter calibration is necessary to obtain the most accurate result. The stored program number for sulfate $\mathrm{SO} 4$ was entered. The display showed in $\mathrm{Mg} / \mathrm{L} \mathrm{SO}^{4}$ and the ZERO icon. A clean sample cell was filled with $10 \mathrm{ml}$ sample to be analyzed. The content of one sulfaver 4 sulfate reagent powder pillow was added to the sample cell. The cell was capped and inverted several times to mix. Press timer A 5 minute reaction program will begin. The cell was allowed to stand undisturbed. After the timer beeped, a second sample cell was filled with $10 \mathrm{ml}$ of sample (the blank). The blank was placed into the cell holder. The sample cell was tightly covered with the instrument cap. The ZERO key was pressed and then display showed $0 \mathrm{mg} / \mathrm{L} \mathrm{SO}_{4}$. The prepared sample was placed into the cell holder. Tightly 
cover the sample cell with the instrument cap within five minutes after the timer beeps. The READ key was pressed and result was displayed in $\mathrm{mg} / \mathrm{l} \mathrm{SO}$.

\section{Calibration procedure}

One thousand parts per million (1000 ppm) sulphate standard solution was prepared by dissolving $0.0256 \mathrm{~g}$ of oven dried magnesium sulphate salt and diluted to $100 \mathrm{ml}$ with deionized water. A $10 \mathrm{ml}$ pipette was used to add $1,2,3,4,5$ and $6 \mathrm{ml}$ of the standard to the 100 $\mathrm{ml}$ volumetric flask, made up to mark with deionized water (This Represents 10, 20, 30, 40, 50 and $60 \mathrm{ppm}$ of the sulphate standards respectively). This was stopper and mixed well. The instrument was zeroed with water while each standard was analyzed using the photometer. The sulphate concentration increased by $10 \mathrm{mg} / \mathrm{l}$ for each $10 \mathrm{ml}$ of standard added. The Calibration curve was plotted of absorbance against $\mathrm{SO} 4$ concentration.

\subsection{Statistical Analysis}

All experiments and analysis were carried out in triplicates. The mean and standard deviation values were calculated. Data were subjected to Analysis of Variance (ANOVA). Means were separated using Tukey's multiple comparison test, and significance accepted at $\mathrm{p} \leq 0.05$ level. The statistical package in Minitab 16 computer program was used.

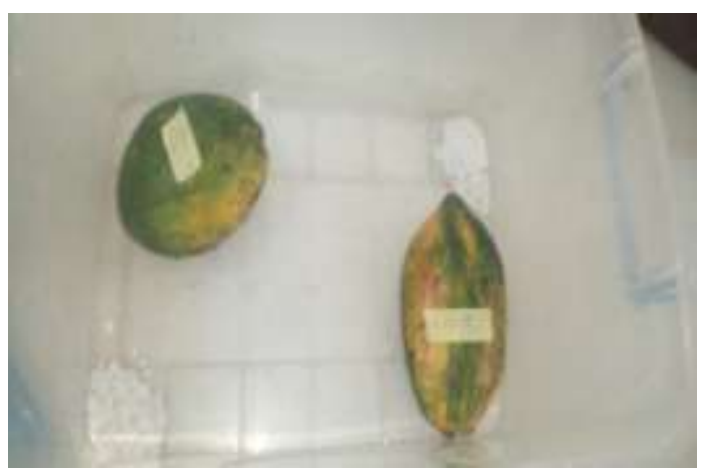

Figure1. Calcium carbide ripened pawpaw fruit

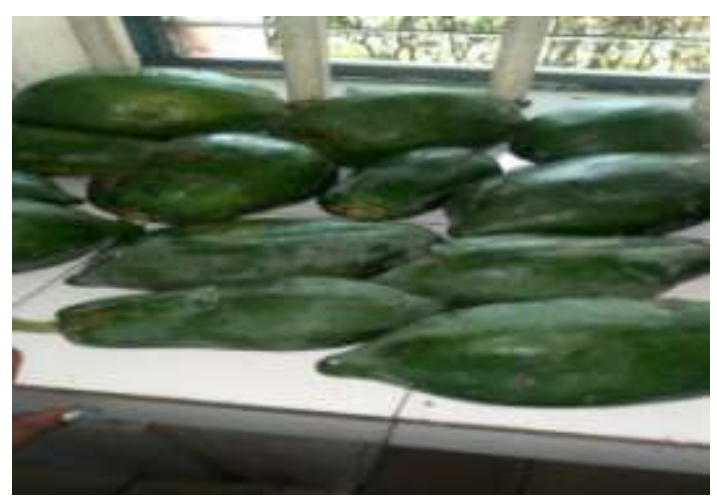

Figure2. Unripe pawpaw fruit

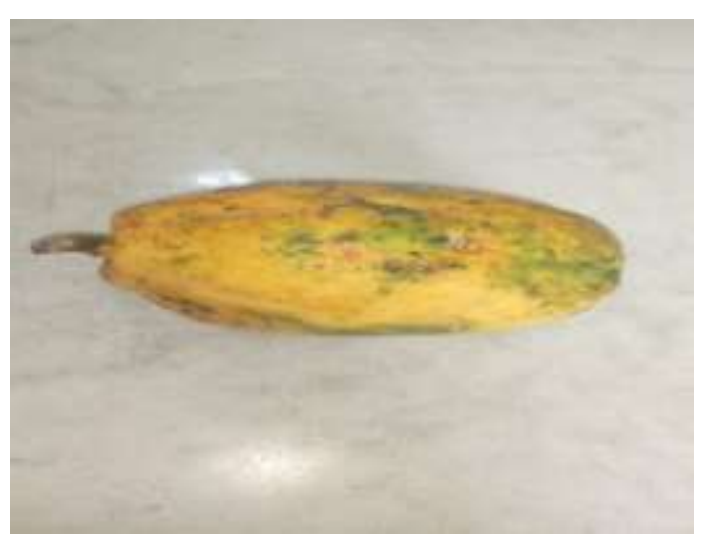

Figure3. Pawpaw fruit ripened with kerosene fumes

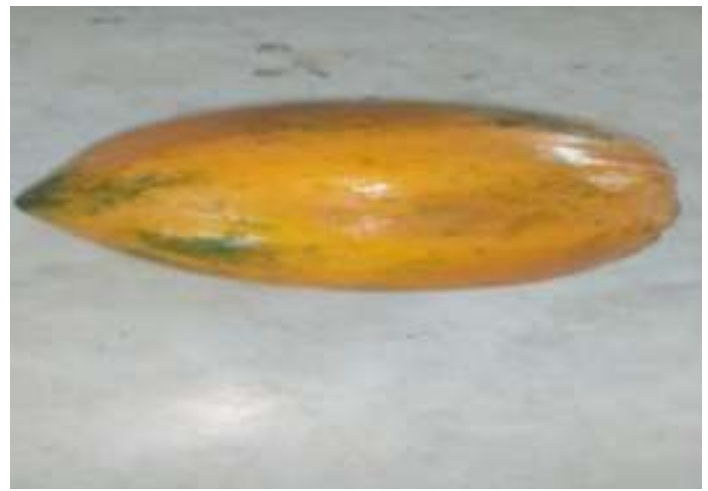

Figure4. Pawpaw fruit ripened naturally

\section{RESUltS AND DISCUSSION}

\subsection{Physico-chemical Properties of Pawpaw Fruit as Affected by Accelerated and Natural Ripening}

Table 1 shows the physico-chemical properties of pawpaw fruit as affected by accelerated and natural ripening. $\mathrm{pH}$ of the ripened and unripened pawpaw fruit ranged from 5.25-6.05. The unripe pawpaw fruit had the highest $\mathrm{pH}$ value while pawpaw ripened with calcium carbide had the lowest. $\mathrm{pH}$ value of the unripe sample was significantly $(\mathrm{p}<0.05)$ different from all other samples while samples ripened with calcium carbide, kerosene fume and naturally ripened samples were significantly $(p<0.05)$ similar. The study also showed a reduction in $\mathrm{pH}$ on accelerated and natural ripening with higher reduction in calcium carbide ripened sample followed by kerosene fume ripened sample. These reductions are due to biochemical reactions which might have taken place in the calcium carbide and kerosene ripened fruits. According to Gbakun et al. [17] natural ripening of fruit involves multiplicity of biochemical pathways. Accelerated ripening of pawpaw fruit with kerosene fume and calcium carbide may probably have interfered with these biochemical pathways thereby reducing its $\mathrm{pH}$. Similar decrease in $\mathrm{pH}$ was also reported by Zenebe et 
al. [18] for banana fruits ripened through kerosene smoking systems. The study also showed that $\mathrm{pH}$ of pawpaw fruit during ripening are slightly acidic in nature with $\mathrm{pH}$ of 5 . It has been reported that fruits with a $\mathrm{pH}$ below 5 can trigger dental erosion [19]. This may suggest that pawpaw fruit ripened with calcium carbide and kerosene will not accelerate dental erosion when consumed.

Total titratable acidity (TTA) is an indication of the amount of acid present in a fruit. Total acidity of pawpaw fruit from the study ranged from $0.14-0.30 \%$. TTA of the natural and accelerated ripened pawpaw fruits were significantly $(\mathrm{p}<0.05)$ different from one another. The result also showed that ripening reduced the total titratable acidity of the fruits and this was more pronounced with natural ripened fruits. The decrease in acidity is due to susceptibility of the predominant acid to oxidative destruction as influenced by the ripening environment. It might also be due to their utilization as substrates for respiration [20]. Haejin et al. [21] investigated the content of organic acid contents in apricot, plumcot, plum, and peach. They also reported that organic acids increased mostly during the early stages of fruit growth and decreased until fruits were fully ripened. Fruits with high acidity have been reported to have implications to dental health as they might cause dental erosion, especially among children [22]. Acidity levels of the natural and accelerated ripened pawpaw fruits were low which indicates that it is safe to dental health.

Total soluble sugars (TSS) of the pawpaw fruits ranged from $7.65^{\circ}$ brix in unripe pawpaw to $12.20^{\circ}$ brix in natural ripened natural pawpaw. There were significant $(\mathrm{p}<0.05)$ differences existing among the fruit. Accelerated and natural ripening resulted to an increase in TSS of the pawpaw fruits. This increase might be due to breakdown of pectin and conversion of carbohydrate and conversion into simple sugars during storage caused by metabolic activities of the tissues [23]. Kafkas et al. [24] investigated the sugar content of strawberry and reported that fructose, the main sugar, increased during ripening. TSS of natural ripened pawpaw was significantly $(p<0.05)$ higher than those ripened with kerosene fume and calcium carbide. Accelerated ripening with calcium carbide and kerosene fumes may probably have interfered with some biochemical pathways during ripening thereby slowing down the increase in
TSS as compared to naturally ripened fruit. Similar finding was also reported by Chwukuma et al. [25] for mango fruits.

Carbohydrate content of the pawpaw fruits ranged from $1.60-4.10 \%$ with unripe sample recording the highest while calcium carbide ripened sample, the lowest. Natural and accelerated ripening had no significant $(p<0.05)$ effect on the carbohydrate content of the pawpaw fruit while the unripe pawpaw fruit was significantly $(p<0.05)$ different from others. The low carbohydrate content of the ripened pawpaw fruit as compared to unripe sample is due to the hydrolysis of carbohydrates into sugars during ripening. The finding of the present study strongly agrees with the study of Iroka et al. [12] for pawpaw ripened with plantain leaf, calcium carbide, hot water, polyethylene bag and smoking.

Moisture content of the pawpaw fruits ranged from $82.32-90.40 \%$ with kerosene fumed pawpaw recording the highest and the naturally ripened pawpaw as lowest. Moisture content of pawpaw ripened with accelerated agents were significantly $(p<0.05)$ higher than the natural ripened pawpaw. This could be due to the fact that these ripening agents (calcium carbide and kerosene fume) probably have interfered with biochemical pathways of pawpaw during ripening thereby increasing its moisture content higher than the natural ripened pawpaw fruit. Similar finding was also reported by Iroka et al. [12] with moisture content of natural ripened pawpaw as $85.32 \%$ and those ripened with plantain leaf, calcium carbide, hot water, polyethylene bag and smoking in the range of $88.28-90.84 \%$. High moisture content of the ripened pawpaw using accelerated ripening agents will expose it to increased microbial spoilage and short shelf life thereby leading to deterioration.

Vitamin $\mathrm{C}$ content of the pawpaw fruits ranged from $0.01 \mathrm{mg} / 100 \mathrm{~g}$ in unripe pawpaw to $0.31 \mathrm{mg} / 100 \mathrm{~g}$ in pawpaw ripened with calcium carbide. The study showed an increasing trend of vitamin $\mathrm{C}$ on ripening. However, vitamin $\mathrm{C}$ content of the fruits were not significantly $(\mathrm{p}<0.05)$ affected by accelerated ripening agents. Vitamin $\mathrm{C}$ content of the pawpaw fruit during ripening were low when compared to values of $50.14-61.09 \mathrm{mg} / 100 \mathrm{~g}$ obtained for pawpaw grown within Nsukka axis [26]. These differences could be due to the method of analysis used, variety of pawpaw fruit and maturity. 
Table1. Physico-chemical Properties of pawpaw during accelerated and natural ripening

\begin{tabular}{|c|c|c|c|c|c|c|}
\hline Treatments & TTA (\%) & pH & Moisture (\%) & Sugar $\left({ }^{\mathbf{0}}\right.$ brix) & $\begin{array}{c}\text { Total Available } \\
\text { Carbohydrate (\%) }\end{array}$ & $\begin{array}{c}\text { Vit. C } \\
(\mathbf{m g} / \mathbf{1 0 0 g})\end{array}$ \\
\hline CCP & $0.23 \pm 0.01^{\mathrm{b}}$ & $5.25 \pm 0.07^{\mathrm{b}}$ & $88.87 \pm 0.47^{\mathrm{ab}}$ & $9.70 \pm 0.14^{\mathrm{b}}$ & $1.60 \pm 0.21^{\mathrm{b}}$ & $0.31 \pm 0.36^{\mathrm{a}}$ \\
\hline KFP & $0.18 \pm 0.01^{\mathrm{c}}$ & $5.32 \pm 0.10^{\mathrm{b}}$ & $90.40 \pm 0.17^{\mathrm{a}}$ & $8.55 \pm 0.07^{\mathrm{c}}$ & $1.67 \pm 0.04^{\mathrm{b}}$ & $0.08 \pm 0.01^{\mathrm{a}}$ \\
\hline NRP & $0.14 \pm 0.00^{\mathrm{d}}$ & $5.42 \pm 0.04^{\mathrm{b}}$ & $82.31 \pm 0.43^{\mathrm{b}}$ & $12.20 \pm 0.00^{\mathrm{a}}$ & $2.35 \pm 0.40^{\mathrm{b}}$ & $0.15 \pm 0.00^{\mathrm{a}}$ \\
\hline UP & $0.30 \pm 0.01^{\mathrm{a}}$ & $6.05 \pm 0.07^{\mathrm{a}}$ & $88.92 \pm 3.42^{\mathrm{ab}}$ & $7.65 \pm 0.21^{\mathrm{d}}$ & $4.10 \pm 0.06^{\mathrm{a}}$ & $0.01 \pm 0.00^{\mathrm{a}}$ \\
\hline
\end{tabular}

Values are means \pm standard deviation of triplicate samples. Mean values bearing different superscript in the same column differ significantly $(\mathrm{P}<0.05)$

Key: $\mathrm{CCP}=\mathrm{Calcium}$ carbide Pawpaw, $\mathrm{KFP}=$ kerosene fume Pawpaw, NRP=natural ripen Pawpaw, UP=unripe Pawpaw

\subsection{Sulphate and Sulphide Distribution (mg/kg) of Pawpaw during Accelerated and Natural Ripening}

Table 2 shows the sulphate and sulphide distribution $(\mathrm{mg} / \mathrm{kg})$ of pawpaw during accelerated and natural ripening. Sulphate (outer and inner) distribution ranged from 0.23$2.34 \mathrm{mg} / 100 \mathrm{~g}$ and $0.67-1.26 \mathrm{mg} / 100 \mathrm{~g}$, respectively. On the other hand, sulphide (outer and inner) distribution ranged from 0.13$0.78 \mathrm{mg} / 100 \mathrm{~g}$ and $0.00-0.28 \mathrm{mg} / 100 \mathrm{~g}$, respectively. There were significant $(\mathrm{p}<0.05)$ differences in the sulphate (outer and inner) and sulphide (outer) distributions of the pawpaw fruit during accelerated ripening. Sulphate (inner) distribution of kerosene fumed ripened pawpaw and unripe pawpaw were significantly $(\mathrm{p}<0.05)$ similar. It was observed that the calcium carbide ripened pawpaw had significantly $(\mathrm{p}<0.05)$ high concentrations of sulphate and sulphide, and this was followed closely with pawpaw ripened with kerosene fume. This could be due to the diffusion of sulphite and sulphate from calcium carbide and kerosene fume to fruit pulp and skin during these ripening processes. Similar finding was also reported by Islam et al. [27] who indicated significantly higher sulfur content in calcium carbide-treated banana samples than the naturally ripened samples.

Sulphate distribution on the outer (fruit pulp) part of avocado were $1.23 \mathrm{mg} / \mathrm{kg}$ and $2.63 \mathrm{mg} / \mathrm{kg}$ for unripe and kerosene fumed avocados, respectively while that on fruit skin were $0.46 \mathrm{mg} / \mathrm{kg}$ and $0.51 \mathrm{mg} / \mathrm{kg}$, respectively with kerosene fumed avocado recording higher sulphate content (on both skin and pulp). Sulphate content on the pulp of kerosene fumed avocado and unripe avocado fruits were significantly $(\mathrm{p}<0.05)$ similar while significant $(p<0.05)$ differences were observed for sulphate content on the inner part. For sulphide distribution on the outer and inner parts, kerosene fumed avocado $(1.95 \mathrm{mg} / \mathrm{kg}$ and $3.03 \mathrm{mg} / \mathrm{kg}$, respectively) had sulphide contents significantly higher $(\mathrm{p}<0.05)$ than that of unripe avocado $(0.008 \mathrm{mg} / \mathrm{kg}$ and $0.010 \mathrm{mg} / \mathrm{kg}$ for outer and inner parts, respectively).

Sulphate distribution on the outer and inner parts of the kerosene fumed pawpaw fruits were higher than that obtained for avocado and mango fruits as reported by Orisa et al. [28]. Sulphate distribution of the calcium carbide treated pawpaw fruit was also higher than the study of Orisa et al. (2020) for mango fruit. Kerosene contains impurities like sulfur (emitted as SOx), aromatic compounds and hydrocarbons [29]. On the other hand, calcium carbide reacts with water to produce acetylene, which behaves similarly to the ethylene gas, a natural ripening hormone [10]. Elemental analysis of calcium carbide also indicates the presence of arsenic and phosphorous [11]. When applied as a ripening agent, sulfur, arsenic and phosphorous from calcium carbide may diffuse into the peel and flesh of fruits and may pose serious health risk. Inhalation of $\mathrm{SO}_{2}$ (4-6 ppm) for $10 \mathrm{~min}$ decreases airway conductance (increased airway resistance) of a healthy person. Acute exposure to high concentration of sulfur dioxide can also cause pulmonary injuries which sometimes lead to death [27]. The maximum level of sulphites permitted by the FAO/WHO [30] in fresh fruits with surface treatment is $50 \mathrm{mg} / \mathrm{kg}$. In this study, it was found that the sulphide and sulphate concentrations were below the limit indicating that the fruits were still safe for consumption against health threats posed by high concentrations of sulphate.

Table2. Sulphate and Sulphide Distribution $(\mathrm{mg} / \mathrm{kg}$ ) of pawpaw during accelerated and natural ripening

\begin{tabular}{|c|c|c|c|c|}
\hline Treatments & Sulphate (Outer) & Sulphate (Inner) & Sulphide (Outer) & Sulphide (Inner) \\
\hline CCP & $2.34 \pm 0.24^{\mathrm{a}}$ & $1.26 \pm 0.16^{\mathrm{a}}$ & $0.78 \pm 0.04^{\mathrm{a}}$ & $0.28 \pm 0.05^{\mathrm{a}}$ \\
\hline KFP & $1.68 \pm 0.24^{\mathrm{b}}$ & $1.08 \pm 0.04^{\mathrm{a}}$ & $0.30 \pm 0.04^{\mathrm{b}}$ & $0.05 \pm 0.01^{\mathrm{b}}$ \\
\hline UP & $0.23 \pm 0.11^{\mathrm{c}}$ & $0.67 \pm 0.08^{\mathrm{b}}$ & $0.13 \pm 0.03^{\mathrm{c}}$ & $0.00 \pm 0.00^{\mathrm{b}}$ \\
\hline
\end{tabular}


Values are means \pm standard deviation of triplicate samples. Mean values bearing different superscript in the same column differ significantly $(\mathrm{P}<0.05)$

Key: $\mathrm{CCP}=\mathrm{Calcium}$ carbide Pawpaw, $\mathrm{KFP}=$ kerosene fume Pawpaw, UP=unripe Pawpaw

\section{CONCLUSION}

This study determined the effect of accelerated ripening agents on the fruit quality of pawpaw. The physicochemical properties and sulphide and sulphate distributions of naturally, accelerated ripened and unripe pawpaw samples were measured and compared. Vitamin $\mathrm{C}$ content of all the pawpaw samples did not show any significant difference. $\mathrm{pH}$ and total available carbohydrate of pawpaw ripened naturally and with accelerated ripening agents were significantly similar. However, total titratable acidity was drastically lowered in naturally ripened pawpaw than all other samples while the moisture contents of accelerated ripened samples were higher than the naturally ripened sample. In addition, sugar content increased on ripening and this was higher for naturally ripened pawpaw samples. Elemental analysis of the two accelerated ripening agents (calcium carbide and kerosene fume) revealed that, the carbide sample contained significantly high amount of sulphate and sulphide. However, the sulphide and sulphate concentrations were below the maximum permissible limit indicating that the fruits were still safe for consumption against health threats posed by high concentrations of sulphate.

\section{REFERENCES}

[1] J.P. Fabi and S.B.R. Prado, "Fast and Furious: Ethylene-Triggered Changes in the Metabolism of Papaya Fruit During Ripening," Frontiers in Plant Science, 2019. Available at https://doi.org.10.3389/fpls.2019.00535.

[2] S.D.T. Maduwanthi and R.A.U.J. Marapana, R.A.U.J, "Induced ripening agents and their effects on fruit quality of banana," International Journal of Food Science, 2019. https://doi.org/10.1155/2019/2520179.

[3] S, Gandhi, M, Sharma and B, Bhatnagar, "Comparative study on the ripening ability of artificial ripening agent (calcium carbide) and natural ripening agents," Global Journal of Biology, Agriculture and Health Sciences, vol 5, pp 106-110, 2016.

[4] J.A.T. Da Silva, Z, Rashid, D.T. Nhut, D. Sivakumar, A. Gera, M.T. Souza Jr and P.F. Tennant, P.F, "Papaya (Carica papaya L.)," Biology and Biotechnology. Tree For Sci Biotech, vol 1, pp 47-73, 2007.
[5] N.E. Gapper, R.P. McQuinn and J.J. Giovannoni, "Molecular and genetic regulation of fruit ripening," Plant Mol. Biol. vol 82, pp 575-591, 2013. https://doi.org/10.1007/s11103013-0050-3.

[6] P. Lü, S. Yu, N. Zhu, Y.R. Chen, B. Zhou and Y. Pan, "Genome encode analyses reveal the basis of convergent evolution of fleshy fruit ripening," Nat. Plants, vol 4, pp 784-791, 2018. https://doi.org/10.1038/s41477-0180249-z.

[7] D.B. Kiin-Kabari, Q. Igbo and L.I. Barber, "Production and evaluation of table wine from different varieties of pawpaw (Carica papaya)," Journal of Food Science and Engineering, vol 9, pp 199-209, 2019. https://doi.org/10.17265/21595828/2019.06/002.

[8] M.O. Moses and M.J. Olarenwaju, "Proximate and selected mineral composition of ripe pawpaw (Carica papaya) seeds and skin," Journal of Scientific and Innovative Research, vol 7, pp 75-77, 2018.

[9] M.D.N. Islam, A. Hasnat, M.D.S. Rahman, M. Mursalat, A.H. Rony, M.S. Khan, "A legislative aspect of artificial fruit ripening in a developing country like Bangladesh," Chemical Engineering Research, vol 18, pp 30-37, 2016.

[10] S.A. Fattah and M.Y. Ali, "Carbide ripened fruits- A recent health harzard," Faridpur Medical College Journal, vol 5, pp pp 37, 2010.

[11] M.D.W. Siddiqui and R.S. Dhua, "Eating artificially ripened fruits is harmful," Current Sciences, vol 99, pp1664-1668, 2010.

[12] C.F. Iroka, E. Akachukwu, .R.N. Adimonyemma, N.C. Okereke, and C.O. Nwogiji, "Effects of induced ripening on the proximate, biochemical and mineral compositions of Carica papaya (pawpaw fruit)," European Journal of Medicinal Plants, vol 15, pp 1-10, 2016. https://doi.org/10.9734/EJMP/2016/26260.

[13] AOAC. Official Method of Analysis. Association of Official Agricultural Chemist. $20^{\text {th }}$ Ed. Washington D.C: USA. pp. $102-105$, 2016.

[14] D. Osborne and P. Vogt, "The analysis of nutrients in foods," Academic Press, London, New York, and San Francisco, pp. 47-53, 1978.

[15] R. R. Moest, "Hydrogen sulfide determination by the methylene blue method" Analytical Chemistry, vol 47, pp 1204-1205, 1975.

[16] M.A. Tabtabai, "A rapid method for determination of sulphate in water samples," Environmental letters. vol 7, pp 237-243, 1974. https://doi.org/10.1080/00139307409437403. 
[17] S.A. Gbakun, T.S. Ubwa, U.J. Ahilem, O.G. Obochi, I.A. Nwannadi, M.I. Yusufu, "Calcium carbide treatment on some physicochemical characteristics of broken and mummy mango fruits," American Journal of Food Technology. 13(1), 23-31, 2018.

[18] W.A. Zenebe, A.M. Ibrahim, B.Y. Derbew, A.W.M. Tarekegn, "Effect of traditional kerosene smoking and ethrel on ripening, shelf life and quality of Cavendish banana (Musa sp), African Journal of Agricultural Research, vol 10, pp 4570-4583, 2015. Https://doi.10.5897/AJAR2015.10299.

[19] M. Unaegbu, G.A. Engwa, Q.D. Abaa, S.O. Aliozo, E.L. Ayuk, G.A. Osuji and E.I. Onwurah, "Heavy metal, nutrient and antioxidant status of selected fruit samples sold in Enugu, Nigeria," International Journal of Food Contamination. vol 3, pp 31- 39, 2016.

[20] A. Hossain, M. Rana, Y. Kimura and H.A. Roslan, "Changes in biochemical characteristics and activities of ripening associated enzymes in mango fruit during the storage at different temperatures," BioMed Research International, 2014. https://doi.org/10.1155/2014/22969.

[21] B. Haejin, Y. Seok Kyu, Y. Ik Koo, N. Eun Young, K. Jung Hyun and J. Ji Hae, "Assessment of organic acid and sugar composition in apricot, plumcot, plum, and peach during fruit development," Journal of Applied Botany and Food Quality, vol 87, pp 24-29, 2014. https://doi.org/10.5073/JABFQ.2014.087.004.

[22] F. Enam, M. Mursalat, U. Guha, M.I. Anik, N.S. Nisha and M.S. Khan, "Dental erosion potential of beverages and bottled drinking water in Bangladesh," International Journal of Food Properties. vol 20, 2016. https://doi.org/10.1080/10942912.2016.124260 7.

[23] K.G.I.R. Jayathunge, D.K.S.N. Gunawardhana, D.C.K. Illeperuma, U.G. Chandeajith, B.M.K.S. Thilakarathne, M.D. Fernando and K.B. Palipane, "Physicochemical and sensory quality of fresh cut papaya (Carica papaya) packaged in micro-perforated polyvinyl chloride containers," Journal of Food Science and Technology, vol 5, pp 3918-3925, 2018.

[24] E. Kafkas, M. Kosar, S. Paydas, S. Kafkas and K.H.C. Baser, "Quality characteristics of strawberry genotypes at different maturation stages," Food Chemistry, vol 100, pp 12291236 , 2007. https://doi.org/10.1016/j.foodchem.2005.12.005

[25] O.M. Chukwuma, F.C. Iroka, E.E. Akachukwu, N.R. Adimonyemma and O.A. Mbaukwu, "A study of the effects of induced ripening on the proximate, biochemical and mineral compositions of Musa sapientum (Banana)," International Journal of Food Science and Nutrition, vol 1, pp 15-20, 2016.

[26] E. Ezeh, O. Okeke, A.C. Ozuah and R.O. Onwubiko, "Comparative assessment of the effects of ripening stage on the vitamin C contents of selected fruits grown within Nsukka axis of Enugu State," International Journal of Environment, Agriculture and Biotechnology, vol 2, pp 712-714, 2017. https://dx.doi.org/10.22161/ijeab/2.2.19.

[27] N. Islam, M.Y. Imtiaz, S.S. Alam, F. Nowshad, S.A. Shadman and M.S. Khan, "Artificial ripening on banana (Musa Spp.) samples: Analyzing ripening agents and change in nutritional parameters," Cogent Food and Agriculture, vol 4, pp 14-27, 2018.

[28] Orisa, C.A., Usoroh, C.I. and Ujong, A.E. (2020). Accelerated ripening agents and their effect on the quality of Avocado (Persia americana M.) and Mango (Mangifera indica L.) fruits. Asian Journal of Advances in Agricultural Research, 14(2): 29-40.

[29] M. Khan, S. Khan, S. Mirza, M. Beg, A Faraz and Khan, "Ethanol-kerosene blends: fuel option for kerosene wick stove," International Journal of Engineering Research and Applications, vol 3, pp 464-466, 2013.

[30] FAO/WHO, "Codex Alimentarius general standard for food additives. In: Codex Alimentarius general standard for food additives. Rome: Food and Agriculture Organization of the United Nations, 2011.

Citation: Catherine Achese Orisa, Comfort Imeh Usoroh. Effects of Accelerated Ripening Agents on the Fruit Quality of Pawpaw (Carica papaya). ARC Journal of Nutrition and Growth. 2020; 6(2):42-49. DOI:https://doi.org/10.20431/2455-2550.0602006.

Copyright: () 2020 Authors. This is an open-access article distributed under the terms of the Creative Commons Attribution License, which permits unrestricted use, distribution, and reproduction in any medium, provided the original author and source are credited. 